\title{
Biotic potential, fertility and life table of Spodoptera albula (Walker) (Lepidoptera: Noctuidae), under controlled conditions
}

\author{
DÉBORA G. MONTEZANO ${ }^{1}$, ALEXANDRE SPECHT ${ }^{1,2}$, DANIEL R. SOSA-GÓMEZ ${ }^{3}$, \\ VÂNIA F. ROQUE-SPECHT ${ }^{4}$, TARCISO M. BORTOLIN ${ }^{5}$, EDEGAR FRONZA $^{1}$, PATRÍCIA PEZZI $^{1}$, \\ PRISCILA C. LUZ ${ }^{1}$ and NEIVA M. BARROS ${ }^{1}$ \\ ${ }^{1}$ Universidade de Caxias do Sul, Caixa Postal 1352, 95070-560 Caxias do Sul, RS, Brasil \\ ${ }^{2}$ Embrapa Cerrados, BR 020, Km 18, Caixa Postal 08223, 73310-970, Planaltina, DF, Brasil \\ ${ }^{3}$ Embrapa Soja, Rod. Carlos João Strass - Distrito de Warta, Caixa Postal 231, 86001-970 Londrina, PR, Brasil \\ ${ }^{4}$ Faculdade UnB Planaltina, Área Universitária n. 1, Vila Nossa Senhora de Fátima, 73300-000 Planaltina, DF, Brasil \\ ${ }^{5}$ Gravena - Pesquisa, Consultoria e Treinamento Agrícola Ltda. Rod. Dep. Cunha Bueno (SP-253), \\ Km 221,5, Caixa Postal 546, 14870-990 Jaboticabal, SP, Brasil
}

Manuscript received on May 16, 2012; accepted for publication on July 30, 2013

\begin{abstract}
This study aimed to evaluate the biotic potential, life table parameters and fertility of Spodoptera albula (Walker, 1857) under controlled conditions $\left(25 \pm 1^{\circ} \mathrm{C}, 70 \pm 10 \% \mathrm{RH}\right.$ and 14 hour photo phase). The longevity, pre, post and oviposition periods, fecundity and fertility of 13 couples were evaluated. The longevity of females (13.500 days) was significantly higher than those of males (11.154 days). The mean durations of the pre, post and oviposition periods were $2.615,1.769$ and 9.385 days, respectively. The mean fecundity was 1.417 .69 eggs and mean fertility was 1.340 .401 larvae, per female. On average, females copulated 1, 231 times. A strong positive correlation was observed between the number of copulations and fecundity ( $\mathrm{r}=0.847, \mathrm{p}<0.001)$, as well as a strong negative correlation between the number of copulations and the duration of the pre-oviposition period $(r=-0.762, p=0.002)$, and longevity $(\mathrm{r}=-0.788, \mathrm{p}=0.001)$. The biotic potential of $S$. albula was estimated at $8.768 \times 10^{22}$ individuals / female / year. The net reproductive rate (Ro) was 353,904 times per generation and the mean generation time (T) was 37.187 days. The intrinsic rate of increase (rm) was 1,105 , with a finite rate of increase $(\lambda)$ of 3,019 .
\end{abstract}

Key words: armyworm, development, fecundity, reproduction, spermatophore.

\section{INTRODUCTION}

The genus Spodoptera Guenée, 1852 is cosmopolitan and includes many of the most important agricultural armyworm caterpillars (Pogue 2002). S. albula (Walker, 1857) has been recorded from Florida to Southern Texas, throughout the

Correspondence to: Débora Goulart Montezano

E-mail: deiagm@gmail.com
Caribbean, Central America, and from Venezuela south to Paraguay and Southern Brazil (Pogue 2002, Zenker et al. 2010), and Chile (Angulo et al. 2008). S. albula has been erroneously referred to as "Spodoptera sunia (Guenée, 1852)", which is currently recognized as Neogalea sunia (Guenée, 1852), representative of the subfamily Cuculliinae (Poole 1989). 
The larvae of $S$. albula have been recorded as feeding on at least 55 species belonging to 29 plant families (Montezano et al. 2013). Generally the larvae move into crops from the invading plants found between the rows and / or along the edges (González-B 1966, Hallman 1979, Savoie 1988).

In many places, especially in Central America, S. albula makes it unfeasible to develop important crops such as tobacco (Stoyan and Machado 1970, Novo Padrino et al. 1984, 1985, Páez Gázquez and Novo Padrino 1987), cotton (Alcaraz Vieco 1962, González-B 1966), tomato (Gloria-B 1975), cabbage (Armstrong 1994), sesame, soybean (Hallman 1979, 1983), peanuts (Teixeira et al. 2001), sunflower (Pruett and Guamán 2001), papaya (Semillas del Caribe 2010) and even seedling production in forestry nurseries (Vázquez et al. 1999).

The importance of this species is increased by its tolerance to various chemical insecticides and to the Bacillus thuringiensis CrylAc gene (Zenner de Polanía et al. 2008, Amaya et al. 2009). Its importance, motivated studies on its biology (Stoyan and Machado1970, Martin Zequeira 1982, Novo Padrino and Martínez Reyes 1985, La Rosa et al. 1992), its damage potential (Novo Padrino et al. 1984, 1985, Páez Gázquez and Novo Padrino 1987), and on the identification of pheromonal components for behavioral control (Bestmann et al. 1988, Dunkleblum et al. 1995).

This study complements the previous one on immature (Montezano et al. 2013) and aims to evaluate and describe the developmental biological parameters of $S$. albula, with special emphasis on its biotic potential and on its life table and fertility, under controlled conditions.

\section{MATERIALS AND METHODS}

All experiments were carried out in a climate controlled room $\left(25 \pm 1{ }^{\circ} \mathrm{C}, 70 \pm 10 \% \mathrm{RH}\right.$ and a 14 hour photo phase), with daily observations. Information on the origin of insects, rearing methodology and data on immature stages are described in detail by Montezano et al. (2013) and all procedures were carried out according to the international practices for animal use and care under the control of an internal committee of the Universidade de Caxias do Sul, Brazil.

Considering the previously described incompatibilities between biotypes of the fall armyworm, from different host plants or localities, during copulation (Murúa and Virla 2004, Sadek and Anderson 2007, Murúa et al. 2008), the insects used in the experiment belong to the first generation obtained from a female collected in the field (see Montezano et al. 2013). Adults were kept in pairs $(\mathrm{n}=13)$ within cylindrical plastic containers, $10 \mathrm{~cm}$ in diameter and $15 \mathrm{~cm}$ high, with tops closed using plastic film, to which container long filter paper strips were attached, to stimulate oviposition. The bottom part of the container was closed with a Petri dish (10.5 cm diameter), and its bottom was lined using filter paper.

To avoid the effect of the pupal weight on the reproductive aspects (Tisdale and Sappington 2001), females from pupae weighing $0.19 \mathrm{~g}(\mathrm{n}=6)$ and $0.20 \mathrm{~g}(\mathrm{n}=7)$ and males from pupae weighing $0.17 \mathrm{~g}$ $(\mathrm{n}=7)$ and $0.18 \mathrm{~g}(\mathrm{n}=6)$ were used. Similarly, to avoid the effects of adults age on their capacity to copulate (Kehat and Gordon 1975, Ellis and Steele, 1982, Rogers and Marti Jr 1994), the couples were formed with adults which emerged on the same date.

The food was composed of the diet described by Hoffmann-Campo et al. (1985) which consists of honey (10g), sorbic acid (1g), Methylparaben (1g), sucrose $(60 \mathrm{~g})$, and distilled water $(1000 \mathrm{ml})$. All components were dissolved in distilled water and the obtained solution was kept under refrigeration $\left(7^{\circ} \mathrm{C}\right)$. Pilsen beer was added to the solution at a proportion of $1 / 4$, on a daily basis, and made available to the insects in a $5 \mathrm{~cm}$ in diameter Petri dish lined with cotton wool. Additionally, distilled water was provided for the hydration of the insects, in another $5 \mathrm{~cm}$ cotton lined Petri dish. We calculated the fecundity (number of eggs per female), the fertility 
(number of hatched larvae per female), the longevity and the duration of the pre- oviposition, postoviposition and oviposition periods.

Containers were examined daily to record adult mortality and to remove and record eggs. The fecundity (number of eggs per female), longevity and duration of pre, post and oviposition periods were evaluated. Dead females were dissected to determine the number of spermatophores they received from males while copulating.

To estimate fertility, the viability of 16 egg clusters taken from four couples, including the first and last, totaling 4,454 eggs were evaluated. To this end, each egg cluster was individualized in a Petri dish, whose bottom was lined with filter paper moistened with distilled water, where it remained until the eclosion of the larvae. All the evaluated egg clusters were from couples whose females, after death, had two spermatophores in the bursa copulatrix, proving they had been fertilized during the experiment.

All biological parameters were analyzed using descriptive statistics with the calculation of means and standard deviations. The means were compared using a t-test assuming unequal variances, at a significance level of $95 \%$. The fecundity, longevity of both sexes and the duration of pre, post and oviposition periods were correlated (Pearson Product Moment Correlation) with the number of matings of each couple.

After gathering the biological parameters, the Biotic Potential (BP) was calculated considering the resistance of the environment as being null, using the equation described in Silveira Neto et al. (1976), $\mathrm{BP}=(\mathrm{sr} * \mathrm{~d})^{\mathrm{n}}$ - er, where: $(\mathrm{sr})$ sex ratio is number of females divided by number of females plus number of males; (d) viable individuals per female consisting of the number of eggs per female (or fecundity) multiplied by total immature survival; (n) number of generations per year or 365 days divided by total lifespan and (er) environmental resistance, in this case considered as null.
The fertility life table was developed using data from the immature stages of $S$. albula provided by Montezano et al. (2013) and is presented graphically by plotting the probability of survival values at the midpoint of each interval, or survival (lx), and the total number of eggs per female per week, which became females, or specific fertility (mx).

Using the life table, the values of the different reproductive parameters of $S$. albula were calculated. The net reproductive rate (Ro), the ratio between the number of females in two successive generations; the mean generation time $(\mathrm{T})$, the mean number of days from the birth of the parents to the birth of offspring; the daily intrinsic rate of increase (rm) and the daily finite rate of increase $(\lambda)$, followed the formulas contained in Silveira Neto et al. (1976).

\section{RESULTS AND DISCUSSION}

In this study, the longevity of S. albula (Table I) was similar to that described by La Rosa et al. (1992) who reported 12.4 days at $25^{\circ} \mathrm{C}$ and 13.2 days at room temperature (average of $26.7^{\circ} \mathrm{C}$ ). However, these values were higher than those described by Martin Zequeira (1982) ( 10.8) at approximately $21^{\circ} \mathrm{C}$ and by Novo Padrino et al. (1985) who reported values of 10, 8 and 7 days at 19.60, 23.03 and $25.30^{\circ} \mathrm{C}$, respectively.

TABLE I

Longevity, pre, post and oviposition periods and fecundity of 13 pairs of Spodoptera albula, under controlled conditions $\left(25 \pm 1^{\circ} \mathrm{C}, 70 \pm 10 \% \mathrm{RH}\right.$ and a 14 hour photo phase).

\begin{tabular}{|c|c|c|c|c|}
\hline & & Mean & $\begin{array}{c}\text { Standard } \\
\text { Deviation }\end{array}$ & Range \\
\hline \multirow{6}{*}{ 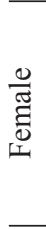 } & Longevity (days) & 12.46 & 2.39 & $8-17$ \\
\hline & Longevity (days) & 13.50 & 1.73 & $11-17$ \\
\hline & Pre-oviposition (days) & 2.67 & 1.30 & $1-5$ \\
\hline & Post-oviposition (days) & 1.42 & 1.08 & $0-3$ \\
\hline & Oviposition (days) & 9.42 & 1.56 & $7-11$ \\
\hline & Fecundity (eggs) & $1,417.75$ & 55.68 & $606-2298$ \\
\hline$\frac{\frac{0}{\pi}}{\sum}$ & Longevity (days)* & 11.42 & 2.57 & $8-16$ \\
\hline
\end{tabular}

Comparison of male and female mean longevity using Student $t$ test, considering different variances, at a $95 \%$ level of significance $(* \mathrm{p}<0.05)$. 
Considering the Montezano et al. (2013) data, which indicates a mean duration of the immature stages as 31.52 days, the average longevity of $S$. albula corresponds to $28.32 \%$, or more than one quarter of their life cycle. These results are similar to other studies involving Spodoptera (i.e. Mattana and Foerster 1988, Habib et al. 1983, Bavaresco et al. 2004, Busato et al. 2005). These results also indicate that the extended longevity of $S$. albula, like other species of the genus such as $S$. dolichos (Fabricius, 1794), S. eridania (Stoll, 1782), S. exigua (Hübner, 1808), S. frugiperda (J.E. Smith, 1797) and S. ornithogalli (Guenée, 1852) which have a great ability for dispersal and even migration (Ferguson et al. 1991), is related to its wide distribution within the American Continent, extending between the parallels $30^{\circ}$ North and South (Pogue 2002, Angulo et al. 2008, Zenker et al. 2010).

On average each female had 1.23 copulations, noting that three $(23.08 \%)$ did not copulate, four copulated only once $(30.77 \%)$ and six copulated twice $(46.15 \%)$. This mean value is within the range described for $S$. frugiperda by Murúa et al. (2008), who found very discordant values between different S. frugiperda populations in Argentina (0.78 to 2.32 spermatophores per female). Regarding the absence of copulation in some $S$. albula pairs, these same authors reported that in some $S$. frugiperda cohorts more than $20 \%$ of the females did not mate, while in other cohorts more than $20 \%$ of couples performed more than two copulations. Moreover, considering that Milano et al. (2008), using 25 S. frugiperda pairs per cage, obtained a mean of over three spermatophores per female with a maximum of six, at $25^{\circ} \mathrm{C}$, it is expected that a greater number of $S$. albula individuals per cage also increases the number of copulations.

The longevity of $S$. albula females was significantly higher than males (Table I) and was negatively correlated with the number of matings ( $r=-0.788$, $\mathrm{p}=0.001$ ) indicating that $S$. albula, similar to $S$. littoralis (Kehat and Gordon 1975, Ellis and Steele 1982), presents a prolonged longevity as a result of reduced and delayed mating. Rogers and Marti Jr (1997) determined that when there is only a single opportunity for mating, two days after the emergence was the optimum age for mating $S$. exigua females to achieve their maximum reproductive potential, but they lived the fewest number of days. Additionally, Hou and Sheng (1999) describe a reduction in longevity of $H$. armigera (Hübner, 1808) females which have multiple matings. These authors attribute these results to interactions between egg production and metabolism. Multiple matings further stimulate egg production and accelerate energy and material consumption, decreasing resources available for somatic maintenance.

With respect to the different longevity between sexes, in studies with representatives of Spodoptera, some authors found greater longevity of females [i.e. Santos et al. 1980 - S. cosmioides (Walker, 1858); Melo and Silva 1987, Garcia and Clavijo 1989, Santos et al. 2004 - S. frugiperda; Farahani et al. 2011 - S. exigua], others of males [i.e. Parra et al. 1977, Mattana and Foerster 1988 - S. eridania; Bavaresco et al. 2003 S. cosmioides; Xue et al. 2010 - S. exigua] or some even found no statistical differences between sexes [i.e. Habib et al. 1983 - S. cosmioides, Botton et al. 1998 - S. frugiperda, Santos et al. 2005 - S. eridania]. Considering that the longevity of males, was hardly correlated with the number of matings $(\mathrm{r}=-0.112$, $p=0.715)$, the results of this study allow us to infer that the greater longevity of females with respect to males is due to the reduced number of copulations.

A strong negative correlation between number of copulations and the pre-oviposition period $(\mathrm{r}=$ -0.762, $\mathrm{p}=0.002$ ) was observed, indicating that $S$. albula presents an extension of the pre-oviposition as a function of the reduced number and absence of mating, which is also reflected as prolonged longevity, similar to $S$. littoralis (Kehat and Gordon 1975, Ellis and Steele 1982), S. exigua (Rogers and Marti Jr 1997), Helicoverpa armigera (Hübner, 1808) (Hou and Sheng 1999) and Trichoplusia ni (Hübner, [1803]) (Ward and Landolt 1995). 
However, there was no significant correlation between the number of copulations and oviposition period $(\mathrm{r}=-0.300, \mathrm{p}=0.319)$ and post-oviposition period $(r=0.216, p=0.479)$. Nevertheless, the reduction of the oviposition period related to a larger number of copulations, as described by Hou and Sheng (1999), is certainly related to a higher reproductive activity in females which copulated more.

The relatively short pre-oviposition period (Table I) indicates that $S$. albula adults complete sexual maturity soon after emergence, as occurs with other Spodoptera representatives (i.e. Parra et al. 1977, Habib et al. 1983, Mattana and Foerster 1988, Tisdale and Sappington 2001). However, the onset of oviposition, at least in the first days after emergence, is conditioned on the occurrence of the first mating. This initial mating period should be near the second day after the emergence of both sexes, as described in Rogers and Marti Jr (1997) for S. exigua.

The average fertility of $S$. albula, with approximately 1,400 eggs per female (Table I) is relatively high when compared with the mean values indicated for the same species in other publications such as: 930 eggs by Alcaraz Vieco (1962); 548, 542 and 995 eggs under mean temperatures of 25,30 and $26,7^{\circ} \mathrm{C}$, by La Rosa et al. (1992); and between 800 to 1,400 eggs by Novo Padrino and Martínez Reyes (1985). Such variations are relatively common and reported in studies with $S$. cosmioides (i.e. Habib et al. 1983, Bavaresco et al. 2003, 2004), S. eridania (Parra et al. 1977, Mattana and Foerster 1988, Santos et al. 2005), S. exigua (i.e. Greenberg et al. 2001, Tisdale and Sappington 2001, Farahani et al. 2011), S. frugiperda (i.e. Santos et al. 2004, Busato et al. 2005, Barros et al. 2010) and S. litura (Fabricius, 1775) (Xue et al. 2010). However, the variations can be attributed to several factors such as the conditions of each experiment and the biotypes related to the different host or geographic regions (i.e. Giolo et al. 2002, Murúa and Virla 2004, Sadek and Anderson 2007, Busato et al. 2008, Murúa et al. 2008). Nevertheless, the greater number of eggs obtained in this study indicates that the diet and methodology employed to rear the immatures (Montezano et al. 2013) and adults were suitable for the development of S. albula in laboratory.

Although high, fertility varied greatly between individuals (Table I), with a positive correlation ( $\mathrm{r}$ $=0.847, \mathrm{p}<0.001$ ) between the number of eggs and number of copulations. The positive relationship between fecundity and number of copulations has been documented for S. exigua (Rogers and Marti Jr 1996), S. frugiperda (Snow et al. 1970, Rogers and Marti Jr 1994, Milano et al. 2008), S. littoralis (Ellis and Steele 1982, Sadek and Anderson 2007), Spodoptera litura (Fabricius, 1797) (Chu and Yang 1991) and other noctuids such as H. armigera (Hou and Sheng 1999) and Trichoplusia ni (Hübner, [1803]) (Ward and Landolt 1995, Landolt 1997). The use of material gained from spermatophores for the production of eggs is one of the demonstrated benefits of "re-mating" which is received by females of other Lepidoptera (not Noctuidae) (i.e. Boggs and Watt 1981, Greenfield 1983). In addition, increases in fecundity are related to hormonal effects in multiple mating females, as indicated by Zeng et al. (1997) for Heliothis virescens (Fabricius, 1977).

Our results, together with the various publications that present a positive relationship between fecundity and fertility, indicate that if somehow the number of copulations were anticipated and increased, by using multiple couples per cage (Milano et al. 2008), the fecundity of $S$. albula could be even greater.

The high egg viability $(94.54 \%)$ is certainly related to the proven fertilization of females who had two spermatophores. This percentage agrees with the $94-98 \%$ reported by Novo Padrino and Martínez Reyes (1985) and generally refers to Spodoptera representatives in studies where multiple mating is known to enhance the reproductive capacity, including fertility (Kehat and Gordon 1975, Sadek 2001, Sadek and Anderson 2007, Busato et al. 2008, Milano et al. 2008).

The biotic potential of $8.686 \times 10^{22}$ individuals per female per year, resulting from the equation 
$\mathrm{BP}=(\mathrm{sr} * \mathrm{~d})^{\mathrm{n}}-$ er $\therefore \mathrm{BP}=(0,515 \times 1,130.400)^{8.296}$ -0 , is obtained when we consider that: 141 female and 133 male immature reached the pupal stage, at a ratio of 0.515 (Montezano et al. 2013); on average each female oviposited 1,417.75 eggs and the overall survival was $79.73 \%$, obtaining $1,130.40$ viable individuals per female (see Montezano et al. 2013, Table I); the average duration of the life cycle (43.99 days), corresponds to 8.29 generations per year (n); and the environmental resistance as null. In other words, each female could generate more than 86 sextillion offspring.

This relatively high value can also be obtained using published data for other representatives of Spodoptera. For example, for S. exigua, at $26^{\circ} \mathrm{C}$, using data from Greenberg et al. (2001), considering an average lifespan of seven days, for larvae fed with cabbage, cotton, pepper, pigweed and sunflower, we get approximate values of $2.1 \times 10^{26}, 3.8 \times 10^{33}$,
$3.6 \times 10^{28}, 5.4 \times 10^{37}$ and $1.6 \times 10^{28}$, respectively. For $S$. eridania, at $27^{\circ} \mathrm{C}$, using data from Parra et al. (1977) and considering a sex ratio of 0.5 or $1: 1$, gives roughly $6.6 \times 10^{23}$ and $6.8 \times 10^{18}$, for larvae reared on cotton and soybean, respectively.

The maximum rate of population increase occurred between the $36^{\text {th }}$ and $37^{\text {th }}$ day, during the $5^{\text {th }}$ week of life, represented by the crossing of the survival and specific fertility lines (Figure 1). This rate is relatively dislocated towards the beginning of the adult stage, especially driven by the higher fertility and low mortality of imagos shortly after emergence. These observations agree with other studies conducted with representatives of Spodoptera where higher values of fecundity are observed during the first few days, from the second or third to the seventh (i.e. Kehat and Gordon 1975, Sadek 2001, Bavaresco et al. 2004, Murúa and Virla 2004).

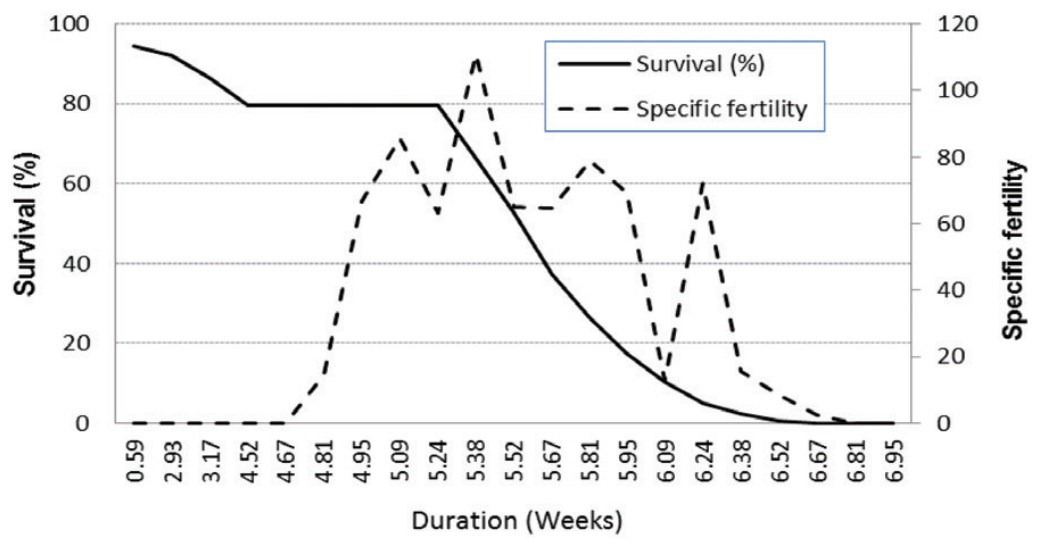

Fig. 1 - Fertility $(\mathrm{mx})$ and survival rate (lx) of Spodoptera albula reared on artificial diet at $25 \pm 1{ }^{\circ} \mathrm{C}, 70 \pm 10 \% \mathrm{RH}$ and a 14 hour photo phase.

The net reproductive rate (Ro) was 353.90 females per generation, similar to values described for other Spodoptera representatives on different host plants: for S. exigua - 377.11 on Chenopodium album Linn. - Chenopodiaceae and 342.11 on cabbage Brassica napus Linn. Brassicaceae (Farahani et al. 2011); for S. exigua - 359.3 on cotton - Gossypiun hirsutum Linn - Malvaceae, 342.2 on sunflower - Helianthus annuus Linn. - Asteraceae, and the maximum value of 596.0 on pigweed - Amaranthus retroflexus Linn. - Amaranthaceae (Greenberg et al. 2001); for S. cosmioides - 313.6 on castorbean Ricinus communis Linn. - Euphorbiaceae and 380.7 on onion - Alliun cepa Linn. - Liliaceae (Bavaresco et al. 2003); and for S. frugiperda - 372.2 on cotton (leaf), 363.2 (leaf and boll), 330.5 on millet (leaf), 421.8 on soybean (leaf) and 501.7 on corn (leaf) (Barros et al. 2010). Due to the great variability of 
hosts (Montezano et al. 2013), it is expected that like other representatives of the same genus (Greenberg et al. 2001, Bavaresco et al. 2003, Barros et al. 2010, Farahani et al. 2011), the net reproductive rate (Ro) of $S$. albula varies greatly as a function of the hosts with higher values for preferred plants, both weeds and crops (i.e. Alcaraz Vieco 1962, González-B 1966, Gloria-B 1975, Hallman 1979, 1983, Novo Padrino et al. 1984, 1985, Páez Gázquez and Novo Padrino 1987, Savoie 1988, Armstrong 1994, Teixeira et al. 2001, Montezano et al. 2013).

The mean generation time ( $\mathrm{T}$ ) of 37.19 days was above the maximum described for $S$. exigua of $\sim 31.6$, at $26^{\circ} \mathrm{C}$ (Greenberg et al. 2001, Farahani et al. 2001) and for $S$. frugiperda of $\sim 30.8$, at $25^{\circ} \mathrm{C}$ (Barros et al. 2010). However, it was less than the minimum observed for $S$. cosmioides of $\sim 47.2$, at $26^{\circ} \mathrm{C}$ (Bavaresco et al. 2003).

The daily intrinsic rate of increase ( $\mathrm{rm}$ ) and the daily finite rate of increase $(\lambda)$ of $S$. albula obtained in the present study were: $\mathrm{rm}=0.158$ and $\lambda=1.171$, respectively. These relatively low values, resemble those obtained for $S$. cosmioides (Bavaresco et al. 2003) which had a higher mean generation time (T), compared with that of S. exigua (Greenberg et al. 2001, Farahani et al. 2011) and S. frugiperda (Barros et al. 2010).

The parameters calculated for $S$. albula resemble some of the values obtained with certain host plants of $S$. cosmioides (Bavaresco et al. 2003), S. exigua (Greenberg et al. 2001, Farahani et al. 2011), and S. frugiperda (Barros et al. 2010). However, one must consider that there are great variations between values for the same species, especially due to temperature and host plant or artificial diet (i.e. Parra et al. 1977, Mattana and Foerster 1988, Ali and Gaylor 1992, Greenberg et al. 2001, Bavaresco et al. 2003, 2004, Busato et al. 2005, Santos et al. 2005, Azidah and SofianAzirun 2006, Sá et al. 2009, Barros et al. 2010, Farahani et al. 2011). Furthermore, Murúa et al. (2008) showed huge variations between biological and reproductive parameters between cohorts of $S$. frugiperda from different locations and host plants in Argentina.

S. albula shares diverse biological characteristics with the other representatives of the genus, considered key pests of various cultures. Among the analyzed parameters, the relatively long duration of the biological cycle is noted and should be further studied to assess whether it is responsible for the greater importance of this species in warmer regions, such as in Central America (i.e. Alcaraz Vieco 1962, González-B 1966, Stoyan and Machado 1970, Gloria-B 1975, Hallman 1979, 1983, Novo Padrino et al. 1984, 1985, Páez Gázquez and Novo Padrino 1987, Armstrong 1994, Vázquez et al. 1999, Pruett and Guamán 2001, Semillas del Caribe 2010), where the life cycle is shortened as a function of temperature.

This study indicates the importance of particularizing every aspect of the reproductive biology, since many details can compromise the data of reproductive parameters and the full expression of the biotic potential of $S$. albula and other Lepidoptera. In this way, when a single couple of S. frugiperda was used (Murúa et al. 2008) in comparison to multiple couples per cage (Milano et al. 2008), it caused a reduction in the mating number, in turn, it was associated with an increase in longevity and in the pre-oviposition period, leading to a decrease in fecundity and fertility.

Our results also indicate concerns for the need of a better understanding of the reproductive parameters of S. albula in the field, such as studies which include the collection of adults of other species using light traps (Sadek 2001), in order to compare with data obtained in the laboratory so that more reliable relationships can be inferred.

The reduction or delay in the number of copulations negatively influencing the population parameters indicates the relevance of identification studies (Bestmann et al. 1988, Dunkleblum et al. 1995) and the use of pheromones to retard or prevent 
the mating of S. albula in nature, in mating disruption procedures (Cardé and Minks 1995), as a strategy for the Integrated Management of this species.

\section{ACKNOWLEDGMENTS}

To Conselho Nacional de Desenvolvimento Científico e Tecnológico (CNPq), for granting the Master's Fellowship to the first author (Processo 557269/2010-5), for financial assistance (Processo 482627/2010-7) and for the Scientific Initiation Fellowships (Processos 507413/2010-5 and 116893/2011-7). To Mr. Adalberto Membreño Mendoza and Mrs. Ana Cecilia Platero-P, Carla Penz, Eyleen Angulo Camacho, Lidiane Mingote Anselmo, Maria da Conceição Felix Araújo, Mercedes Sáenz Díaz, Nery Hernández Pérez and Silvana Vieira de Paula Moraes, for their precious help during the bibliographical search.

\section{RESUMO}

Este trabalho objetivou avaliar o potencial biótico e parâmetros da tabela de vida e fertilidade de Spodoptera albula (Walker, 1857) em condições controladas (25 $\pm 1^{\circ} \mathrm{C}, 70 \pm 10 \%$ UR e fotofase de 14 horas). Avaliouse a longevidade, períodos de pré, pós e oviposição, fecundidade e fertilidade de 13 casais. A longevidade das fêmeas (13,500 dias) foi significativamente maior que a dos machos (11,154 dias). A duração dos períodos médios de pré, pós e oviposição foram de 2,615, 1,769 e 9,385 dias, respectivamente. A fecundidade média foi de 1.417,69 ovos e a fertilidade 1.340,401 larvas por fêmea. Em média, as fêmeas copularam 1,231 vezes. Observouse forte correlação positiva entre número de cópulas e a fecundidade $(r=0,847, p<0,001)$ e, forte correlação negativa, entre o número de cópulas e a duração do período de pré-oviposição $(\mathrm{r}=-0,762, \mathrm{p}=0,002)$, e a longevidade $(\mathrm{r}=-0,788, \mathrm{p}=0,001)$. O potencial biótico de S. albula foi estimado em $8,768 \times 10^{22}$ indivíduos/fêmea/ ano. A taxa líquida de reprodução (Ro) foi de 353.904 vezes por geração e o tempo médio de uma geração $(\mathrm{T})$ foi de 37,187 dias. A taxa intrínseca de aumento (rm) foi de 1,105 , com uma razão finita de aumento $(\lambda)$ de 3,019.
Palavras-chave: lagarta-militar, desenvolvimento, fecundidade, reprodução espermatóforo.

\section{REFERENCES}

AlCARAZ VieCo H. 1962. Principales plagas Del Algodón em Colombia. Montería: Instituto de Fomento Algodonero, 63 p. (Boletín Técnicon 2).

ALI A AND GAYLOR MJ. 1992. Effects of temperature and larval diet on development of the beet armyworm (Lepidoptera: Noctuidae). Environ Entomol 4(10): 780-786.

Amaya OS, Restrepo OD, ArgüElles J AND AgUilera-G E. 2009. Evaluacion del comportamiento del complejo Spodoptera con la introduccion del algodon transgénico al Tolima, Colombia. Rev Corpoica Cien Tecn Agro 10(1): 24-32.

ANGUlo AO, Olivares TS AND WeIGERT GTH. 2008. Estados Immaduros de Lepidópteros Nóctuidos de Importancia Agrícola y Forestalen Chile y Claves para su identificación (Lepidoptera: Noctuidae). Concepción, Universidad de Concepción, $154 \mathrm{p}$.

Armstrong AM. 1994. Spodoptera sunia (Guenée) [S. albula] (Lepidoptera: Noctuidae): a new record of attack on cabbage in Puerto Rico. J Agric Univ Puerto Rico 78(1-2): 67-68.

AZIDAH AA AND SOFIAN-AzIRUN M. 2006. Life history of Spodoptera exigua (Lepidoptera: Noctuidae) on various host plants. B Entomol Res 96: 613-618.

BARros EM, TORRES JB AND BUENO AF. 2010. Oviposição, desenvolvimento e reprodução de Spodoptera frugiperda (J.E. Smith) (Lepidoptera: Noctuidae) em diferentes hospedeiros de importância econômica. Neotrop Entomol 39(6): 996-1001.

BAVARESCO A, GARCIA MS, GARCIA AD, GRÜTZMACHER R AND FORESTI J. 2004. Adequação de uma Dieta Artificial Para a Criação de Spodoptera cosmioides (Walk.) (Lepidoptera: Noctuidae) em Laboratório. Neo Trop Entomol 33(2): 155-161.

BAVARESCO A, GARCIA MS AND GRUTZMACHER AD. 2003. Biologia comparada de Spodoptera cosmioides (Walk.) (Lepidoptera: Noctuidae) em cebola, mamona, soja e feijão. Cienc Rural 33: 993-998.

Bestmann HJ AtTygalle AB, Schwarz J, Vostrowsky O AND KNAUF W. 1988. Identification of sex pheromone components of Spodoptera sunia Guenée (Lepidoptera: Noctuidae). J Chem Ecol 14(2): 683-690.

BogGs CL AND WATT W. 1981. Population structure of pierid butterflies. IV. Genetic and physiological investiment in offspring by male Colias. Oecologia (Berl.) 50(3): 320-324.

BotTON M, CARbonARI JJ, GARCIA MS AND MARTINS JFS. 1998. Preferência alimentar e biologia de Spodoptera frugiperda (J.E. Smith) (Lepidoptera: Noctuidae) em arroz e capim-arroz. An Soc Entomol Brasil 27(2): 207-212.

Busato GR, LOECK AE, GARCIA MS, Bernardi O, ZART M, NunES AM AND ZAZYCKI LCF. 2008. Compatibilidade reprodutiva entre biótipos "milho" e "arroz" de Spodoptera frugiperda (J.E. Smith) (Lepidoptera: Noctuidae). Rev Bras Agroc 14(2): 273-278. 
Busato GR, Grutzmacher AD, Garcia MS, Giolo FP, ZOTTI MJ, TEFANELlo JR GJ. 2005. Biologia comparada de populações de Spodoptera frugiperda (J.E. Smith) (Lepidoptera: Noctuidae) em folhas de milho e arroz. Neotrop Entomol 34(5): 743-750.

CARDÉ RT AND MinKS AK. 1995. Control of moth pests by mating disruption: successes and constraints. Ann Rev Entomol 40: 559-585.

ChU YI AND YANG SCO. 1991. Ovipositional biology of the tobacco cutworm (Spodoptera litura F.). Chin J Entomol 11: $188-196$.

DUNKLEBum E, RodRíGUEZ-V CL, OECHLSCHLAGER C AND VARGAS-GM. 1995. Desarrollo de la feromona sexual de Spodoptera sunia (Lepidoptera: Noctuidae) em melón. Manejo Integrado de Plagas 37(1): 34-38.

Ellis PE AND STEELE G. 1982. The effect of delayed mating on the fecundity of females of Spodoptera littoralis (Boiduval) (Lepidoptera: Noctuidae). Bull Entomol Res 72(2): 295-302.

FARAhani S, NASERI B AND TAlebi AA. 2011. Comparative life table parameters of the beet armyworm, Spodoptera exigua (Hübner) (Lepidoptera, Noctuidae) on five host plants. J Entomol Res Soc 13(1): 91-101.

Ferguson DC, Hilburn DJ AND Wright B. 1991. The Lepidoptera of Bermuda: their food plants, biogeography, and means of dispersal. Mem Entomol Soc Can 158: 3-105.

GARCIA JL AND CLAVIJO AS. 1989. Efecto de la alimentación sobre la longevidad, fertilidad y fecundidad de Spodoptera frugiperda (Smith). B Entomol Venez 5(3): 47-53.

Giolo FP, GRUTZMCHER AD, GARCIA MS AND BUSATO GR. 2002. Parâmetros biológicos de Spodoptera frugiperda (J.E. Smith 1797) (Lepidoptera: Noctuidae) oriundas de diferentes localidades e hospedeiros. Rev Bras Agro 8: 219-224

GLORIA-B R. 1975. Control químico Del "gusano ejercito" Prodenia sunia (G.) em tomateira. Rev Per Entomol 18(1): 120-123.

GonZÁLEZ-B JB. 1966. Aspectos Importantes sobre la Evolución y Combate de las Plagas del Algodonero en Colombia. Rev Per Entomol 9(1): 145-155.

Greenberg SM, Sappington TW, Legaspi JR BC, LiU TX AND Setamou M. 2001. Feeding and life history of Spodoptera exigua (Lepidoptera: Noctuidae) on different host plants. Ann Entomol Soc Am 94(4): 566-575.

GREENFIELD DM. 1983. The question of paternal nutrient investiment in Lepidoptera: male contributed proteins in Plodia interpunctella. Int J Invertebr Reprod 5: 323-330.

HABIB MEM, PALEARI ML AND AMARAL EC. 1983. Effect of three larval diets on the development of the armyworm, Spodoptera latifascia Walker, 1856 (Lepidoptera: Noctuidae). Rev Bras Zool 1(3): 177-182.

HALLMAN G. 1979. Importancia de algunas relaciones naturales plantas-artrópodos en la agricultura de la zona cálida del Tolima Central. Rev Colomb Entomol 5(3-4): 19-26.

HALlMAN G. 1983. Arthropods associated with soybean in Tolima. Rev Colomb Entomol 9(1): 55-59.
HoFFMANN-CAMPo CB, OLIVEIRA EB AND MoscARDi F. 1985. Criação massal da lagarta da soja (Anticarsia gemmatalis). Londrina: Embrapa-SNPSo, 23 p. (Documentos 10).

Hou ML AND SHENG CF. 1999. Fecundity and longevity of Helicoverpa armigera (Lepidoptera: Noctuidae): effects of multiple mating. J Econ Entomol 92(3): 569-573.

KEHAT MAND GORDON D. 1975. Mating, longevity, fertility and fecundity of the cotton leaf-worm, Spodoptera littoralis (Boisd.) (Lepidoptera: Noctuidae). Phytoparasitica 3(2): 87-102.

LA Rosa J, CABrera R AND Vera R. 1992. Influencia de la temperatura em el desarollo de Spodoptera sunia (Lepidoptera, Noctuidae) em tomata 'Cambell-28'. Protección de Plantas 2(3): 13-21.

LANDOLT PJ. 1997. Cabbage looper (Lepidoptera: Noctuidae) fecundity maximized by a combination of access to water and food, and remating. Ann Entomol Soc Am 90(6): 783-789.

Martin Zequeira CE. 1982. Ciclo biológico de Prodenia sunia. Ciencia y Tecnica en laAgricultura. Proteccion de plantas 5(1): 21-30.

Mattana AL AND Foerster LA. 1988. Ciclo de vida de Spodoptera eridania (Cramer, 1782) (Lepidoptera: Noctuidae) em um novo hospedeiro, Bracatinga (Mimosa scabrella Bentham) (Leguminosae). An Soc Entomol Brasil 17(1): 173-183.

MELo M AND SiLva RFP. 1987. Influência de três cultivares de milho no desenvolvimento de Spodoptera frugiperda (J.E. Smith 1797) (Lepidoptera: Noctuidae). An Soc Entomol Brasil 16(1): 37-49.

Milano P, Berti Filho E, PARRA JRP AND CONSOLI FL. 2008. Influência da temperatura na frequência de cópula de Anticarsia gemmatalis (Hübner) e Spodoptera frugiperda (J.E. Smith) (Lepidoptera: Noctuidae). Neotrop Entomol 37(5): 528-535.

Montezano DG, SPecht A, Bortolin TM, Fronza E, SosA-Gómez DR, RoQue-SPECht VF, Pezzi P, Luz PC AND BARROS NM. 2013. Immature stages of Spodoptera albula (Walker) (Lepidoptera: Noctuidae): developmental parameters and host plants. An Acad Bras Cienc 85: 271-284.

MURÚA MG AND VIRLA E. 2004. Population parameters of Spodoptera frugiperda (Smith) (Lep.: Noctuidae) fed on corn and two predominant grasses in Tucuman (Argentina). Acta Zool Mex (n.s.) 20(1): 199-210.

Murúa MG, Vera MT, Abraham S, JuARÉz ML, Prieto S, HEAD GP AND WILlinK E. 2008. Fitness and mating compatibility of Spodoptera frugiperda (Lepidoptera: Noctuidae) populations from different host plant species and regions in Argentina. Ann Entomol Soc Am 101(3): 639-649.

Novo PADRINO JM AND MARTínez ReYes E. 1985. Ciclo biológico de Spodoptera sunia $(\mathrm{G})$ en condiciones de laboratorio. Cent Agri 12(1): 107-115.

Novo PAdRino JM, MARTínez Reyes E AND HERnÁNDEZ FERNÁNDEZ F. 1984. Relación entre el insecto Spodoptera sunia (Mantequilla) y la planta de tabaco (Nicotiana tabacum). Cent Agri 11(2): 33-38. 
Novo PAdrino JM, MARTínez ReYes E AND HERnÁNDEZ FERNÁNDEZ F. 1985. Determinación del consumo de alimento por instares larvales en Spodoptera sunia (Guene) sobre plantas de tabaco. Cent Agri 12(2): 9-14.

PÁez GÁzQuez B AND Novo Padrino JM. 1987. Comportamiento poblacional de Spodoptera sunia $(\mathrm{Gn})$ en siete variedades de tabaco. Rev CENIC Cienc Biol 18(3): 133-135.

PARRA JRP, PRECETTI AACM AND KARSTEN JR P. 1977. Aspectos biológicos de Spodoptera eridania (Cramer, 1782) (Lepidoptera: Noctuidae) em soja e algodão. An Soc Entomol Brasil 6(2): 147-155.

Pogue GM. 2002. A world revision of the genus Spodoptera Guenée (Lepidoptera: Noctuidae). Mem Am Entomol Soc 43: 1-202.

PoOLE RW. 1989. Lepidopterorum Catalogus (N.S.), fasc. 118, Noctuidae pt. 2, New York: E. J Brill / Flora \& Fauna, $512 \mathrm{p}$.

PRuett CJH AND GuAmán I. 2001. Principios de manejo integrado de plagas y biocontrol en siembra directa, $p$. 121-157. In: Rossello RD (Coord), Siembra Directa em el Cono Sur. Montevideo: PROCISUR, 450 p.

ROGERS CE AND MARTI JR OG. 1994. Reproductive potential of once-mated moths of the fall armyworm (Lepidoptera: Noctuidae). Fla Entomol. 77(4): 402-410.

ROGERS CE AND MARTI JR OG. 1996. Beet armyworm (Lepidoptera: Noctuidae): effects of age at first mating on reproductive potential. Fla Entomol 79(3): 343-352.

ROGERS CE AND MARTI JR OG. 1997. Once-mated beet armyworm (Lepidoptera: Noctuidae): effects of age at mating on fecundity, fertility, and longevity. Environ Entomol 26(3): 585-590.

SÁ VGM, FONSECA BVC, BOREGAS KGB AND WAQUIL JM. 2009. Sobrevivência e desenvolvimento larval de Spodoptera frugiperda (J E Smith) (Lepidoptera: Noctuidae) em hospedeiros alternativos. Neotrop Entomol 38(1): 108-115.

SADEK MM. 2001. Polyandry in field-collected Spodoptera littoralis moths and laboratory assessment of the effects of male mating history. Entomol Exp Appl 98(2): 165-172.

SADEK MM AND ANDERSON P. 2007. Modulation of reproductive behavior of Spodoptera littoralis by host and nonhost plant leaves. Basic Appl Ecol 8(2007): 444-452.

SAntos GP, Cosenza GW AND AlBINo JC. 1980. Biologia de Spodoptera latifascia (Walker, 1856) (Lepidoptera: Noctuidae) sobre folhas de eucalipto. Rev Brasil Entomol 24(2): 153-155.

Santos KB, Meneguim AM AND Neves PMOJ. 2005. Biologia de Spodoptera eridania (Cramer) (Lepidoptera: Noctuidae) em diferentes hospedeiros. Neotrop Entomol 34(6): 903-910.

SANTOS LM, REDAELLI LR, DIEFENBACH LMG AND EFROM CFS. 2004. Fertilidade e longevidade de Spodoptera frugiperda (J.E. Smith) (Lepidoptera: Noctuidae) em genótipos de milho. Ciênc Rural 34(2): 345-350.
SAVOIE KL. 1988. Alimentación selectiva por 20 spécies de Spodoptera (Lepidoptera: Noctuidae) en un campo de frijol con labranza mínima. Turrialba 38(2): 67-70.

SEMILlas Del CARIBE. 2010. Cultivo - Plagas. 44 p. HTTP:// www.semilladelcaribe.com.mx/sc/ar/archi/plagas.pdf. (accessed: Oct. 29.2011).

Silveira-Neto S, NAKANo O, Bardin D AND Villa Nova NA. 1976. Manual de ecologia dos insetos. Editora Agronômica Ceres, 420 p.

SNOw JW, Young JR AND Jones RL. 1970. Competitiveness of sperm in female fall army worms mating with normal and chemosterilized males. J Econ Entomol 63(6): 1799-1802.

Stoyan D AND Machado M. 1970. Ciclo biológico de Prodenia sunia y medidas para su control. Dirección Nacional de Sanidad Vegetal. Série Protección de plantas I, La Habana, 26 p.

TeIXeIra ÉP, NOvo PADRINO JS, STEIN CP AND GOdOY IJ. 2001. Primeiro registro da ocorrência de Spodoptera albula (Walker) (Lepidoptera: Noctuidae) atacando amendoim (Arachis hypogaea L.) no estado de São Paulo. Neotrop Entomol 30(4): 723-724.

TISDALERAAND SAPPINGTON TW. 2001. Realized and potential fecundity, egg fertility, and longevity of laboratory-reared female beet armyworm (Lepidoptera: Noctuidae) under different adult diet regimes. Ann Entomol Soc Am 94(3): 415-419.

VÁZQUEZ LL, MENÉNDEZ JM AND LóPEZ R. 1999. Manejo de insectos de importancia forestal en Cuba. Manejo Integrado de Plagas 54(1): 13-26.

WARD KE AND LANDOLT PJ. 1995. Influence of multiple mating on fecundity and longevity off female cabbage looper moths (Lepidoptera: Noctuidae). Ann Entomol Soc Am 88(6): 768-772.

Xue M, Pang YH, Wang HT, Li QL and Liu TX. 2010. Effects of four plants on biology and food utilization of the cutworm, Spodoptera litura. J Insect Sci 10: 22. www. insectscience.org/10.22. (accessed: Dec. 29.2011).

ZENG F, SHU S, PARK YIAND RAMASWAY SB. 1997. Vitellogenin and egg production in the moth, Heliothis virescens. Arch Insect Biochem. Physiol 34(3): 287-300.

Zenker MM, Botton M, Teston JA AND SPecht A. 2010 Noctuidae moths occurring in grape orchards in Serra Gaúcha, Brazil and their relation to fruit-piercing. Rev Brasil Entomol 54(2): 288-297.

ZENNER de Polanía I, ÁlaVAREZ-RodrígueZ JA, ArÉVAlOMALDONADO HÁ, MEJÍA-CRUZ R AND BAYONA MA. 2008. Susceptibilidad de cuatro noctuidos plaga (Lepidoptera) al gene Cry1Ac del Bacillus thuringiensis incorporado al algodonero. Rev Colomb Entomol 34(1): 41-50. 